\title{
Salinity Variability of Soda Meadow Alkaline Soil in Different Depths of Subsurface Pipe
}

\author{
Yan Wang ${ }^{1}$, Sen Dou ${ }^{1 *}$, Lili Wang², Jinsong Wu ${ }^{3}$, Tao Wang ${ }^{1}$, Changyu Wang ${ }^{4}$, \\ Zhendong Jiang ${ }^{3}$, Zhengshan $\mathrm{Ju}^{5}$, Jun Wang ${ }^{5}$, Ming Luo ${ }^{5}$ \\ ${ }^{1}$ Jilin Agricultural University, Changchun, China \\ ${ }^{2}$ School of Life Science, Anhui University, Hefei, China \\ ${ }^{3}$ Da'an Land and Resources Bureau, Da'an, China \\ ${ }^{4}$ Land Consolidation and Rehabilitation Center of Jilin Province, Changchun, China \\ ${ }^{5}$ Key Laboratory of Land Consolidation and Rehabilitation, Ministry of Land and Resources, Beijing, China
}

Received: 31 July 2017

Accepted: 21 November 2017

\begin{abstract}
The study investigates the impact of subsurface pipes at different depths on physicochemical properties of soda meadow alkaline soil. Field experiments were carried out in 5 treatments: CK (no treatment), CK1 (treatment with comprehensive supplementary measures: subsoiling to $0.6 \mathrm{~m}$ and applying farm manure in the amount of $34 \mathrm{~m}^{3} / \mathrm{hm}^{2}$, then mulching with sandy soil of $500 \mathrm{~m}^{3} / \mathrm{hm}^{2}$ ), and 3 treatments of comprehensive supplementary measures combined with subsurface pipes at different depths $(\mathrm{H} 1=0.8 \mathrm{~m}$, $\mathrm{H} 2=1.0 \mathrm{~m}$, and $\mathrm{H} 3=1.2 \mathrm{~m}$ ). The results suggest that soil permeability, organic matter content, available nitrogen, available potassium, and cation exchange capacity (CEC) in all treatments were significantly improved except for CK. The application of comprehensive supplementary measures improved soil pH, electrical conductivity (EC), total salt content (TS), total alkalinity (TA), and sodium adoption rate (SAR). Compared to $\mathrm{CK} 1$, treatments of $\mathrm{H} 1, \mathrm{H} 2$, and $\mathrm{H} 3$ decreased TS, TA, and exchangeable sodium percentage (ESP). Moreover, the treatment with shallow buried pipe $(\mathrm{H} 1=0.8 \mathrm{~m})$ decreased more in soil $\mathrm{pH}, \mathrm{EC}$, and SAR, and promoted more in rice yield than the other treatments. These results suggest that shallow buried subsurface pipe ( $0.8 \mathrm{~m}$ in depth and $5 \mathrm{~m}$ in space) has the best amelioration in soda saline-alkali soil region, when the same rice-planting and comprehensive supplementary measures were adopted.
\end{abstract}

Keywords: subsurface pipe, buried depth, soda meadow alkaline soil, soil ions composition, salinity variability

\section{Introduction}

China has vast areas of saline-alkali soils distributed mainly in inland basins and alluvial plains in the arid

*e-mail: dousen1959@126.com

and semi-arid areas of northern China [1]. Soda salinealkali soil, a type of saline-alkali soil, is predominantly composed of $\mathrm{Na}_{2} \mathrm{CO}_{3}$ and $\mathrm{NaHCO}_{3}$. It is estimated that more than $3,937,000$ ha of soda saline-alkali soils are distributed in Songnen plain in northeastern China [2], which makes Songnen the third-largest concentrated distribution area of saline-alkali soil in the world [34]. Low crop productivity is found in saline-sodic soils, 
which are strongly alkaline with poor soil structure and nutrients [5-7]. However, Songnen Plain has been one of the most important grain-producing regions, given its location in a high-latitude rain-fed area. In recent decades many technical approaches have involved improving saline-alkaline soils with regard to the increasing demand for food with the growth in population [8]. For example, planting rice to help salt leaching and create a shallow soil desalination layer, but with a drawback of saline return once the water layer has disappeared [9]; planting alkaline-tolerant species to increase crop yields [10]; building bulging strips or barriers in the field; applying organic fertilizer or soil amendments [11]; and culturing arbuscular mycorrhiza (AM) to help plants capturing nutrients [12]; etc.

Except for the above methods, subsurface pipe drainage has had a long history since the 19th century because it had advantages in salt drainage and water table control. Compared to conventional drainage, subsurface pipe drainage could save land occupation and reduce water use. Also, it has been adapted to different types of soil. However, it was seldom concerned in soda salinealkali soil considering the weaker water infiltration rate [13].

The subsurface drainage system (SDS) consists of porous pipes buried underground by an expert drainage trencher. Plenty of excess water around pipes was required to solute saline alkali soil. Then surface salty water was collected by porous pipes and drained centrally out of soil.

In SDS, pipe diameter, buried depth, and spacing are the most important engineering parameters. Weather, soil type, terrain, and vegetation et al. are also related [14-16]. For example, pipes buried deep (approximate $3 \mathrm{~m}$ ) and sparsely were adopted by the United States [17], whereas the approach of shallow and narrowly designed subsurface drainage, with depth 0.8-1.5 m and distance $20-40 \mathrm{~m}$, has been taken by India, Iran, and Japan [18-19]. A previous study reported that the deeper the pipes were buried, the less time cost for water declining to the same table, and consequently the faster the average declining rate; simultaneously, the closer the pipes, the larger the drainage modulus, water, and salt discharge per unit [20]. Moreover, the research on salinity migration characteristics showed that the closer the pipes were buried, the better salinity removal effect was under the condition of simulated subsurface drainage [21-22]. The optimal parameters from the field experiment were obtained in an inland saline area (Xinjiang, western China) with depth and spacing of $2.0 \mathrm{~m}$ and $50 \mathrm{~m}$, respectively [20]; in a coastal salinealkaline area (Shandong, easten China) with depth and spacing of $1.2 \mathrm{~m}$ and $14 \mathrm{~m}$, respectively; and in paddy soil (Japan) with 0.2-1.0 m depth and 0.2-15 m spacing [23]. Singh et al. calibrated the DRAINMOD model and demonstrated that the optimal water draining strength was $0.46 \mathrm{~cm} \cdot \mathrm{d}^{-1}$ with subsurface pipes $0.6-0.8 \mathrm{~m}$ deep and 14-20 $\mathrm{m}$ apart [24]. Therefore, the relationship between space and depth of subsurface pipes closely depends on the soil type and properties. Distance would be larger if pipes were buried deeper. For soda saline-alkaline soil with poor water filtration, optimal installing model of the subsurface pipes should be shallow and sparse.

In our study, SDS was applied to the newly reclaimed paddy field located in western Jilin province, northeastern China. $5 \mathrm{~m}$ in space was adopted according to previous reports [25]. The current study aims to investigate the influence of subsurface pipe at different depths on physicochemical properties and crop production of soda meadow alkaline soil in Songnen Plain. Results reported here may provide a new insight into the method to ameliorate soda saline-alkali soil.

\section{Materials and Methods}

\section{Site Description}

The study area is between Anguang and Honggangzi villages in Da'an, Jilin province of China, locating in the middle of Songnen plain (123⒋ $28.7^{\prime \prime}$ $123^{\circ} 49^{\prime} 20.5^{\prime \prime} \mathrm{E}$, and $45^{\circ} 35^{\prime} 34.5^{\prime \prime} \quad$ - $\left.45^{\circ} 36^{\prime} 12.1^{\prime \prime} \mathrm{N}\right)$. The climate is temperate with continental monsoon. Average annual temperature is $4.3^{\circ} \mathrm{C}$ and average annual accumulated temperature reaches $2,921.3^{\circ} \mathrm{C}$. The mean annual precipitation in this area is $413.7 \mathrm{~mm}$ and the average annual sunshine hours are 3,012.8. Soil type in this area is classified as severe soda meadow alkaline soil. The study was conducted in a paddy field reclaimed in 2010 with area of 37.65 ha. Five plots were selected randomly and each plot was $20 \times 80 \mathrm{~m}$. The experiment was performed from May 2010 to October 2012. Physico-chemical properties of the field prior to reclaiming were: heavy loam soil texture, $1.15 \times 10^{-3} \mathrm{~mm} / \mathrm{min}$ soil permeability, $\mathrm{pH} 10.26$, electrical conductivity $1.07 \mathrm{~ms} / \mathrm{cm}$, and total soil organic matter content of $6.2 \mathrm{~g} / \mathrm{kg}$.

\section{Experimental Design and Field Management}

Two controls were set up, the first (CK) was used as a negative control (neither subsurface pipe nor comprehensive supplementary measures), the second (CK1) was treated with comprehensive supplementary measures: subsoiled to $0.6 \mathrm{~m}$ by an expert scarifier (SD7LGP, China) mulched with sandy soil (organic content $0.8 \mathrm{~g} / \mathrm{kg}, \mathrm{pH} 8.5$ ) of $5 \mathrm{~cm}$ thickness (at $500 \mathrm{~m}^{3} / \mathrm{hm}^{2}$ ) and then applied farm manure (organic content $155 \mathrm{~g} / \mathrm{kg}$ ) in the amount of $34 \mathrm{~m}^{3} / \mathrm{hm}^{2}$.

Three treatments of subsurface pipe combined with comprehensive supplementary measures were set up simultaneously with $5 \mathrm{~m}$ spacing and different depths of H1 $(0.8 \mathrm{~m}), \mathrm{H} 2(1.0 \mathrm{~m})$, and H3 (1.2 m). Corrugated double-wall high-density polyethylene (HDPE) pipes (PE100, DN110) were pre-drilled with diameter 1-3 mm and spacing of $10-20 \mathrm{~mm}$ on top of the pipes. Then the pipes were automatically installed by a drainage trencher (steenbergen Hollanddrain GSS HD P90, Netherlands). 
Every treatment was operated at 3 replications, followed by rice planted in spring 2010. Products in the area of $10 \times 10 \mathrm{~m}$ were harvested in October 2012, based on a ratio of collecting area to planting area of 1:15.

Surface soil at the profile of $0 \sim 20 \mathrm{~cm}$ was collected in October 2011 after rice harvest. Soil samples were randomly taken according to "S" sampling method with the principle of equivalent and multipoint.

\section{Analytical Methods}

Soil $\mathrm{pH}$ and Electronic conductivity (EC) were tested onsite using a portable $\mathrm{pH}$ meter (HI99121, China) and EC meter (HI993310, China). Other items are tested indoors after soil samples were taken to the laboratory and prepared. Soil permeability was identified as the capacity of water passing through soil at $10^{\circ} \mathrm{C}$, represented by the permeability coefficient $\mathrm{K}_{10^{\circ}}$. The formula is given by:

$$
\mathrm{K}_{10}=\mathrm{Kt} /(0.7+0.03 \mathrm{t})
$$

...where $\mathrm{Kt}$ is the permeable coefficient at temperature $\mathrm{t}^{\circ} \mathrm{C}$ with unit $\mathrm{mm} / \mathrm{min}$., and $\mathrm{t}$ is the temperature of infiltrated water monitored continuously until stable (720 min and $18.8^{\circ} \mathrm{C}$ in this study).

Wet sieve analysis was used to test soil aggregates, pipette method for soil texture, and potassium dichromate oxidation for soil organic carbon [26-28]. Alkalihydrolyzable nitrogen was quantified by the method in a previous report [29]. Available $\mathrm{P}$ was determined using $\mathrm{NaHCO}_{3}$ extraction and subsequent colorimetric analysis at $700 \mathrm{~nm}$. Available $\mathrm{K}$ was extracted by shaking with $0.5 \mathrm{M}$ ammonium acetate acid then determined using a flame photometer. The cation exchange capacity (CEC) was given using $\mathrm{NH}_{4} \mathrm{OAC}$ extraction and tested on flame photometry. Total soil salinity (TS) was measured by mass method. $\mathrm{K}^{+}$and $\mathrm{Na}^{+}$were determined by flame photometry. $\mathrm{Ca}^{2+}$ and $\mathrm{Mg}^{2+}$ were determined by titration with EDTA. $\mathrm{CO}_{3}^{2-}$, and $\mathrm{HCO}_{3}^{-}$was determined by the double indicators of phenothalin and bromophenol blue, then titration with $0.01 \mathrm{M}$ sulfuric acid. $\mathrm{Cl}^{-}$was measured by titration with $\mathrm{AgNO}_{3}$. $\mathrm{SO}_{4}{ }^{2-}$ was measured by titration with EDTA. Exchangeable sodium $\left(\mathrm{Na}^{+}\right)$was determined using flame photometry after extraction with $\mathrm{NH}_{4} \mathrm{OAC}$ and $\mathrm{NaOH}$ [30].

Total alkali (TA) was identified as a summary of $\mathrm{CO}_{3}{ }^{2-}$ and $\mathrm{HCO}_{3}^{-}$. Exchangeable sodium percentage (ESP) was consumed as the amount of exchangeable sodium in CEC. Sodium absorbance rate (SAR) was calculated by the formula:

$$
S A R=\frac{\left[\mathrm{Na}^{+}\right]}{\sqrt{\left[\mathrm{Ca}^{2+}\right]+\left[\mathrm{Mg}^{2+}\right]}}
$$

...where $\left[\mathrm{Na}^{+}\right],\left[\mathrm{Ca}^{2+}\right]$, and $\left[\mathrm{Mg}^{2+}\right]$ are the ion concentrations with unit of $\mathrm{mmol} / \mathrm{L}$. All the details can be found in previous reports [31].

\section{Statistical Methods}

Data were collected and analyzed by Microsoft Office Excel 2016. One-way analysis of variance (ANOVA) was performed to compare different treatments of subsurface pipes installed at the $95 \%$ confidence level. Multiple comparisons between 2 treatments were conducted by Tukey's multiple range test. IBM SPSS software (Windows, release 19.0, 2010) was used for all statistical analyses.

\section{Results and Discussion}

\section{Effects of Different Buried Pipe Depths on Soil Physical Properties}

\section{Soil Permeability}

Soil permeability is a basic indicator evaluating the availability of subsurface pipes in controlling soil alkalinity. Varied soil permeability according to different treatments is shown in Table 1 . The permeability in CK was the lowest, with $\mathrm{K}_{10}$ being $0.004 \mathrm{~mm} / \mathrm{min}$, but $\mathrm{K}_{10}$ significantly increased to $0.045 \mathrm{~mm} / \mathrm{min}$ after

Table 1. Effects of different pipes buried depth on permeability and soil aggregate. Samples were obtained in fall 2012. CK was a negative control; CK1 was treated with comprehensive supplementary measures; H1, H2, and H3 were the three treatments of subsurface pipe combined with comprehensive supplementary measures in the spacing of $5 \mathrm{~m}$ and different depths of $\mathrm{H} 1(0.8 \mathrm{~m}), \mathrm{H} 2(1.0 \mathrm{~m})$, and $\mathrm{H} 3(1.2 \mathrm{~m})$. Results were reported by mean \pm SEM of three replicates. Treatments labeled with the same lowercase letter did not differ significantly $(\mathrm{P}<0.05)$.

\begin{tabular}{|c|c|c|c|c|c|}
\hline \multirow{2}{*}{ Treatment } & \multirow{2}{*}{$\begin{array}{c}\text { Soil permeability } \mathrm{K}_{10} \\
(\mathrm{~mm} / \mathrm{min})\end{array}$} & $>2$ & $0.25 \sim 2$ & $0.053 \sim 0.25$ & $<0.053$ \\
\cline { 3 - 6 } & $0.004 \pm 0.001 \mathrm{e}$ & $5.18 \pm 0.33 \mathrm{a}$ & $6.15 \pm 0.17 \mathrm{a}$ & $58.76 \pm 4.89 \mathrm{a}$ & $29.91 \pm 3.67 \mathrm{a}$ \\
\hline CK & $0.045 \pm 0.002 \mathrm{~d}$ & $4.30 \pm 0.23 \mathrm{~b}$ & $6.29 \pm 0.52 \mathrm{a}$ & $63.64 \pm 1.32 \mathrm{a}$ & $25.77 \pm 1.37 \mathrm{a}$ \\
\hline CK1 & $0.055 \pm 0.002 \mathrm{c}$ & $4.61 \pm 0.01 \mathrm{~b}$ & $5.31 \pm 0.02 \mathrm{~b}$ & $63.02 \pm 5.61 \mathrm{a}$ & $27.06 \pm 1.90 \mathrm{a}$ \\
\hline H3 & $0.064 \pm 0.002 \mathrm{~b}$ & $4.46 \pm 0.01 \mathrm{~b}$ & $5.43 \pm 0.03 \mathrm{~b}$ & $63.75 \pm 3.09 \mathrm{a}$ & $26.36 \pm 4.11 \mathrm{a}$ \\
\hline H2 & $0.075 \pm 0.001 \mathrm{a}$ & $4.25 \pm 0.23 \mathrm{~b}$ & $5.28 \pm 0.10 \mathrm{~b}$ & $65.62 \pm 2.69 \mathrm{a}$ & $24.85 \pm 2.08 \mathrm{a}$ \\
\hline H1 & & & & & \multicolumn{4}{|c|}{ Soil particle diameter (mm) (\%) } \\
\hline
\end{tabular}


applying comprehensive improvement measures in CK1 $(\mathrm{P}<0.05)$. Compared to $\mathrm{CK} 1$, soil permeability was significantly enhanced $(\mathrm{P}<0.05)$ in the treatments of $\mathrm{H} 1 \quad(0.075 \mathrm{~mm} / \mathrm{min}), \mathrm{H} 2 \quad(0.065 \mathrm{~mm} / \mathrm{min})$, and H3 (0.055 $\mathrm{mm} / \mathrm{min})$, indicating that combining subsurface pipe and comprehensive supplementary measures in soda alkaline soil synergistically promoted soil permeability. This is probably because soil texture and structure were promoted by rice planting combined with organic fertilizer application, when soil water migration improved as a result and salty water drained out of the subsurface pipe. Afterward, the speed of soil alkali leaching increased, resulting in soil salt content decreasing and a virtuous cycle being created.

\section{Soil Aggregation}

Soil aggregation as storage and cycling of soil organic carbon and total nitrogen can significantly affect soil stability and fertility [32]. Aggregates are often grouped by size: macroaggregates $(>0.25 \mathrm{~mm})$ and microaggregates $(<0.25 \mathrm{~mm})$ with these groups being further divided by size [32-33]. In this study soil particle size was predominantly distributed in $0.053 \sim 0.25 \mathrm{~mm}$ and less than $0.053 \mathrm{~mm}$ in diameter (Table 1). The results of Tukey's multiple range test showed that compared to $\mathrm{CK}$, particle sizes larger than $2 \mathrm{~mm}$ significantly decreased $(\mathrm{P}<0.05)$ after utilization of the soil improvement method (CK1) and the installation of subsurface pipes (H1 to H3). Nevertheless, there were no significant differences among the 5 treatments in terms of particles sizes ranging $0.053 \sim 0.25 \mathrm{~mm}$ and $<0.053$ $(\mathrm{P}>0.05)$. Compare to control (CK and CK1), the particle diameter in $0.25 \sim 2 \mathrm{~mm}$ was significantly decreased in the treatments with subsurface pipe installed, whereas no significant decrease $(\mathrm{P}>0.05)$ was detected among the treatments of different depths of subsurface pipes. The data indicated that the application of subsurface pipe combined with comprehensive supplementary measures and subsoiling had a positive affect on the aggregate structure of the soil.

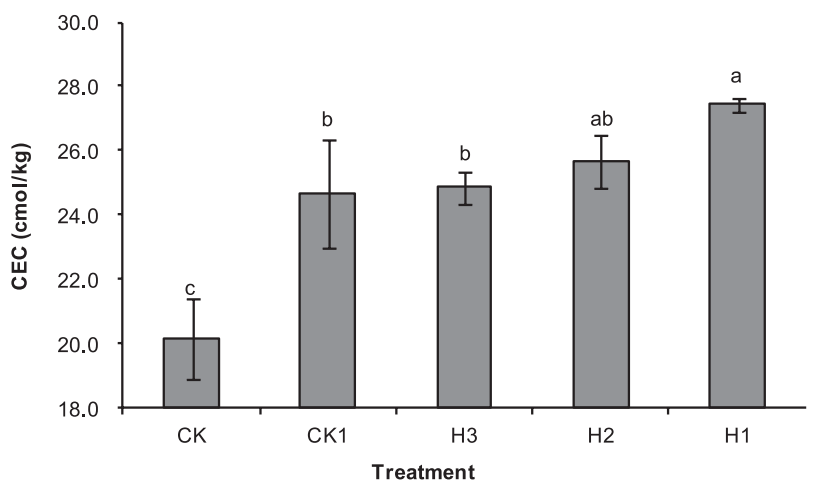

Fig. 1. Variation of soil CEC under different subsurface pipe depths. Samples were obtained in fall 2012. CK was a negative control; CK1 was treated with comprehensive supplementary measures; $\mathrm{H} 1, \mathrm{H} 2$, and $\mathrm{H} 3$ were the 3 treatments of subsurface pipe combined with comprehensive supplementary measures in the spacing of $5 \mathrm{~m}$ and different depths of $\mathrm{H} 1(0.8 \mathrm{~m}), \mathrm{H} 2$ $(1.0 \mathrm{~m})$, and H3 $(1.2 \mathrm{~m})$. Error bars = standard error. Treatments labeled with the same letter are not significantly different form one another at $\mathrm{P} \leq 0.05$. (The same description applies to the other figures.)

\section{Effects of Different Pipe Depths on Soil Nutrients and Rice Yield}

Soil organic matter (SOM) was the most active ingredient to supply nutrients for plants, which is recognized as one of the important indicators for soil fertility. As shown in Table 2, the content of SOM was low in CK $(9.57 \mathrm{~g} / \mathrm{kg})$, whereas it significantly increased $(\mathrm{P}<0.05)$ after applying the comprehensive supplementary measures (CK1). Compare to CK1, significant differences of SOM were observed in the treatments of $\mathrm{H} 1, \mathrm{H} 2$, and $\mathrm{H} 3$, which increased $3.58 \mathrm{~g} / \mathrm{kg}$, $3.28 \mathrm{~g} / \mathrm{kg}$, and $3.10 \mathrm{~g} / \mathrm{kg}$, respectively. This demonstrated that subsurface pipe combined with comprehensive supplementary measures synergistically promoted SOM content by accelerating crop growth. The amount of organic matter entering soil was increased as a result and the increased SOM content making subsurface pipe work well in reverse [34].

Table 2. Effect of pipe buried depth on soil organic matter, available nutrient content, and rice yield. Samples were obtained in fall 2012. CK was a negative control; CK1 was treated with comprehensive supplementary measures; H1, H2, and H3 were the 3 treatments of subsurface pipe combined with comprehensive supplementary measures in the spacing of $5 \mathrm{~m}$ and different depths of $\mathrm{H} 1(0.8 \mathrm{~m})$, H2 $(1.0 \mathrm{~m})$, and $\mathrm{H} 3(1.2 \mathrm{~m})$. Results were reported by mean \pm SEM of 3 replicates. Treatments labeled with the same letter did not differ significantly $(\mathrm{P}<0.05)$.

\begin{tabular}{|c|c|c|c|c|c|}
\hline Treatment & $\begin{array}{c}\text { SOM } \\
(\mathrm{g} / \mathrm{kg})\end{array}$ & $\begin{array}{c}\text { Available N } \\
(\mathrm{mg} / \mathrm{kg})\end{array}$ & $\begin{array}{c}\text { Olsen-P } \\
(\mathrm{mg} / \mathrm{kg})\end{array}$ & $\begin{array}{c}\text { Available K } \\
(\mathrm{mg} / \mathrm{kg})\end{array}$ & $\begin{array}{c}\text { Rice yield } \\
\left(\mathrm{kg} / \mathrm{hm}^{2}\right)\end{array}$ \\
\hline $\mathrm{CK}$ & $9.57 \pm 0.09 \mathrm{~d}$ & $43.25 \pm 4.23 \mathrm{~b}$ & $27.15 \pm 1.59 \mathrm{a}$ & $61.47 \pm 2.03 \mathrm{~b}$ & $2526 \pm 360 \mathrm{c}$ \\
\hline $\mathrm{CK} 1$ & $12.14 \pm 0.30 \mathrm{c}$ & $45.24 \pm 2.02 \mathrm{ab}$ & $28.60 \pm 3.10 \mathrm{a}$ & $67.65 \pm 2.55 \mathrm{a}$ & $5000 \pm 986 \mathrm{~b}$ \\
\hline H3 & $12.67 \pm 0.16 \mathrm{~b}$ & $47.84 \pm 2.38 \mathrm{ab}$ & $28.46 \pm 1.08 \mathrm{a}$ & $68.21 \pm 2.77 \mathrm{a}$ & $6071 \pm 414 \mathrm{ab}$ \\
\hline H2 & $12.78 \pm 0.18 \mathrm{ab}$ & $48.36 \pm 4.15 \mathrm{ab}$ & $29.12 \pm 3.27 \mathrm{a}$ & $69.18 \pm 3.92 \mathrm{a}$ & $6905 \pm 984 \mathrm{a}$ \\
\hline H1 & $13.15 \pm 0.08 \mathrm{a}$ & $49.27 \pm 1.23 \mathrm{a}$ & $30.21 \pm 2.06 \mathrm{a}$ & $72.64 \pm 3.25 \mathrm{a}$ & $7405 \pm 664 \mathrm{a}$ \\
\hline
\end{tabular}




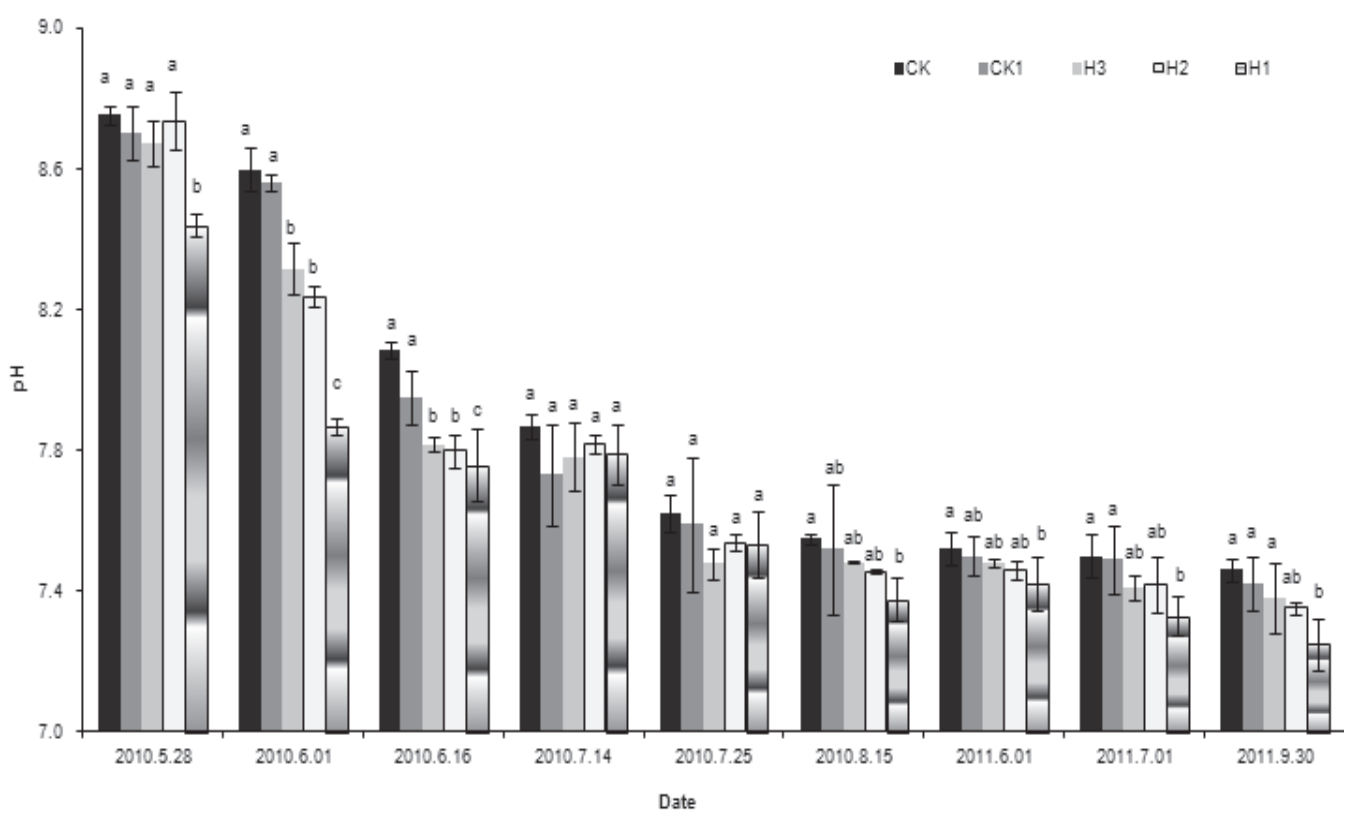

Fig. 2. Variation of soil $\mathrm{pH}$ under different subsurface pipe depths.

Soil nutrient is the necessary element that crops absorbed in soil for growing, which is also one of the important indicators for evaluating soda meadow alkaline soil fertility. The effect of subsurface pipe on soil nutrient content is shown in Table 2. Compared to CK, the contents of alkali-hydrolyzable nitrogen and available potassium were significantly increased $(\mathrm{P}<0.05)$ in the treatment of CK1, but the content of available phosphorus was not significantly different. Compared to CK1, the content of alkali-hydrolyzable nitrogen, available potassium, and phosphorus were not significantly increased in the treatments of $\mathrm{H} 1, \mathrm{H} 2$, and $\mathrm{H} 3(\mathrm{P}<0.05)$. This indicated that subsurface pipe plus comprehensive supplementary measures had great impact on available nutrients.

Rice yield was low in the treatments of $\mathrm{CK}$ $\left(2,480 \mathrm{~kg} / \mathrm{hm}^{2}\right)$ while it was higher in the treatment of CK1 $\left(5,050 \mathrm{~kg} / \mathrm{hm}^{2}\right)$, which indicated that implementing comprehensive supplementary measures was effective and necessary. On the basis of CK1, rice yield was significantly increased with the utilization of subsurface pipe. The maximum output was seen in the treatment of $\mathrm{H} 1$ with $7,500 \mathrm{~kg} / \mathrm{hm}^{2}$. The results suggested that the design of shallower buried subsurface pipe could get more rice yield (Table 2).

\section{Effect of Different Pipe Depths on Soil Salinity and Composition}

The value of total salinity (TS) could reflect soil salinity condition and dynamic variations. In this study, TS was high in CK, which is $3.57 \mathrm{~g} / \mathrm{kg}$. Compared to $\mathrm{CK}$, TS significantly decreased $(\mathrm{P}<0.05)$ in the treatment of CK1. Compared to CK1, TS in the treatments of $\mathrm{H} 1, \mathrm{H} 2$, and $\mathrm{H} 3$ significantly decreased as $1.56 \mathrm{~g} / \mathrm{kg}, 1.11 \mathrm{~g} / \mathrm{kg}$, and $1.04 \mathrm{~g} / \mathrm{kg}$, respectively $(\mathrm{P}<0.05)$. The data showed that subsurface pipe combined with comprehensive supplementary measures in soda alkaline soil had a synergistic effect on TS decrease. Although soil permeability was improved by the comprehensive supplementary measures as shown in Table 1, TS in the different soil layers could not be transported to the subsurface and quickly drained without an outlet. Therefore, the single method had less advantage in promoting soil TS. Combining comprehensive supplementary measures with subsurface pipe was the best way to decrease soil salt content, which not only ameliorated soil permeability, but also helped saline water drain out of the soil. Consequently, the growth of rice root system was promoted and desalination of the soil was accelerated [35].

Cation exchange capacity (CEC) directly determined soil performance of fertilizer supply. It is recognized as the larger of soil CEC and the better of soil fertilizer supply. The original soil CEC in Da'an has lower CEC, which is $18.33 \mathrm{cmol} / \mathrm{kg}$ as shown in $\mathrm{CK}$; however, it was significantly enhanced $(\mathrm{P}<0.05)$ after implementing subsurface pipe plus comprehensive supplementary measures (Fig. 3). Although compared to CK1, the treatments of $\mathrm{H} 1$ and $\mathrm{H} 2$ significantly increased, no significant differences were observed in the treatment of $\mathrm{H} 3 \quad(\mathrm{P}<0.05)$. This showed that shallow buried subsurface pipe at less than $1.0 \mathrm{~m}$ was better in soil CEC improvement. This was probably because shallow buried subsurface pipe improved plant growth, leading to organic matter of plant and root residues gradually accumulating as a result.

$\mathrm{pH}$ value in all treatments was lower than $\mathrm{CK}$ and showed a decreasing tendency with rice growing, and this variation of tendency was getting slower during 1 July to 30 September, 2011 (Fig. 4). This result demonstrated that planting rice is a critical factor for decreasing soil $\mathrm{pH}$. And subsurface pipe plus comprehensive supplementary 


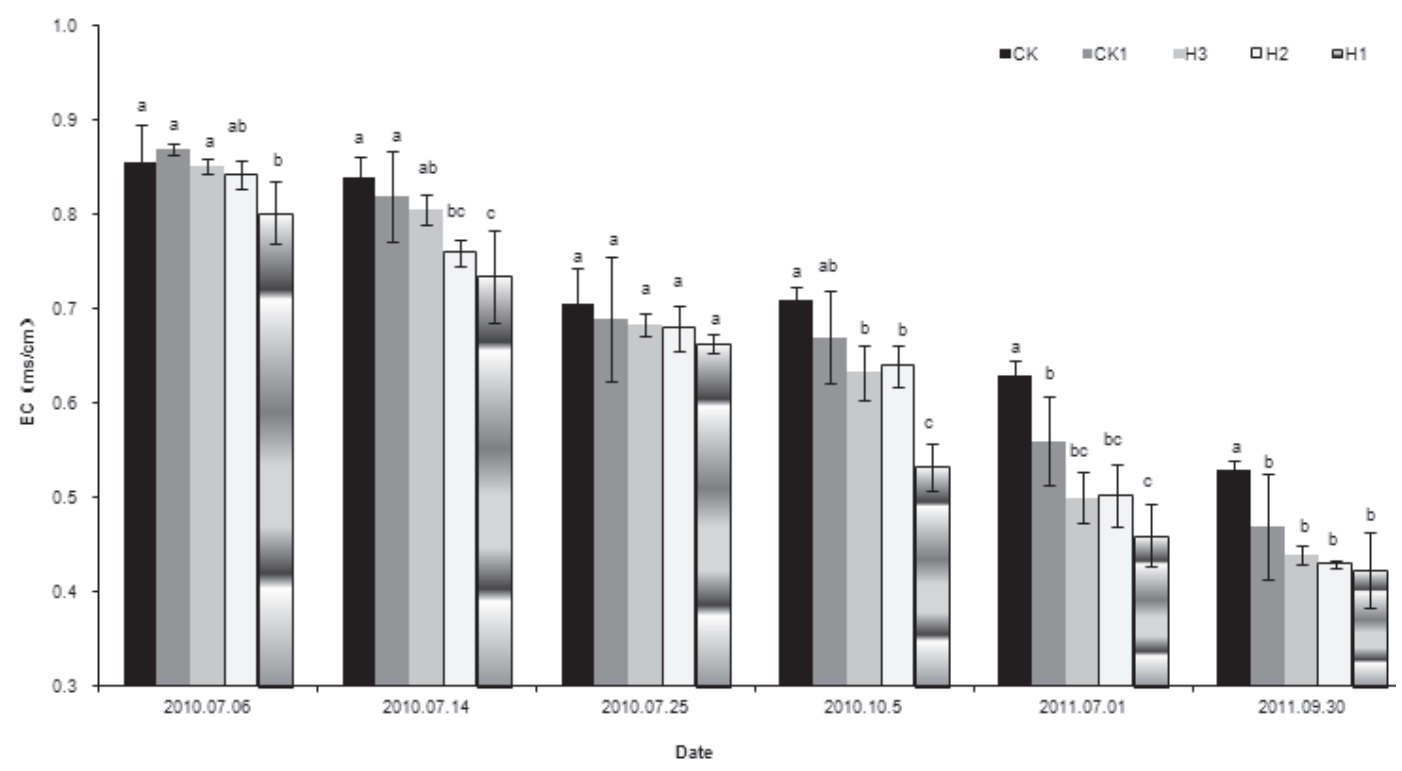

Fig. 3. Variation of soil electrical conductivity under different subsurface pipe depths.

measures had a great effect on decreasing soil $\mathrm{pH}$ as well. Compared to $\mathrm{CK} 1, \mathrm{pH}$ value in the $\mathrm{H} 1$ treatment showed decreases during the rice-growing period except from 14-25 July 2010. $\mathrm{pH}$ value in treatments $\mathrm{H} 2$ and H3 significantly decreased $(\mathrm{P}<0.05)$ in June 2010 and on 1 July 2011. This demonstrated that shallow buried subsurface pipe had a positive effect on decreasing $\mathrm{pH}$.

The value of electrical conductivity (EC) is an important indicator that reflects the content variations of water-soluble salt in soil, which is redistributed and accumulated because of the movement of underground water [36]. EC is also used to evaluate whether the salt ion is the limiting factor for plant growth. In our study, EC in all treatments showed a decreasing tendency with rice growth (Fig.5). Compared to $\mathrm{CK}$, EC in the treatment of CK1 significantly decreased $(\mathrm{P}<0.05)$ in 2011 ; whereas no significant decrease was observed during the rice growing period except 5 Oct. 2010. Compared to CK1, the treatment of $\mathrm{H} 1$ showed the lowest EC during the entire monitoring period except 25 July 2010 and 30 September 2011; the H2 treatment showed a significantly decrease

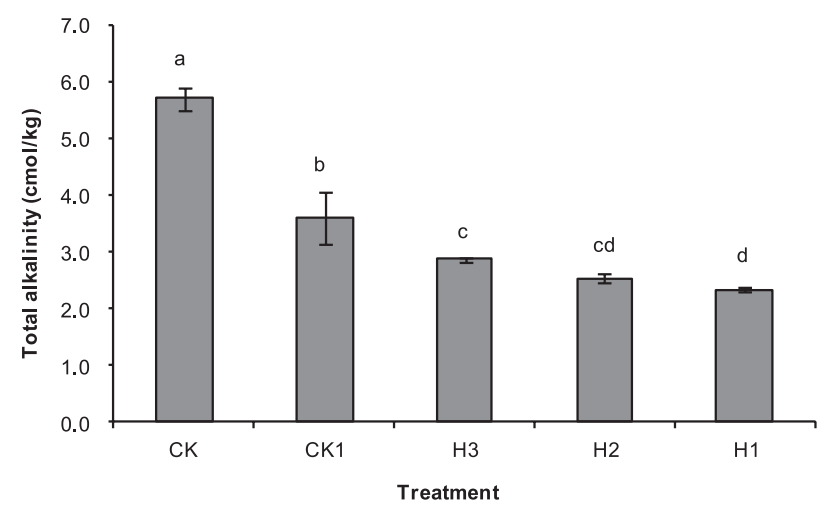

Fig. 4. Total alkalinity (TA) of the soil under different subsurface pipe depths; samples were obtained in fall 2012.
$(\mathrm{P}<0.05)$ except on 25 July 2010 and 30 September 2011; and treatment $\mathrm{H} 3$ showed the same tendency only during 14 July and 5 October 2010, and 1 July 2011. The results

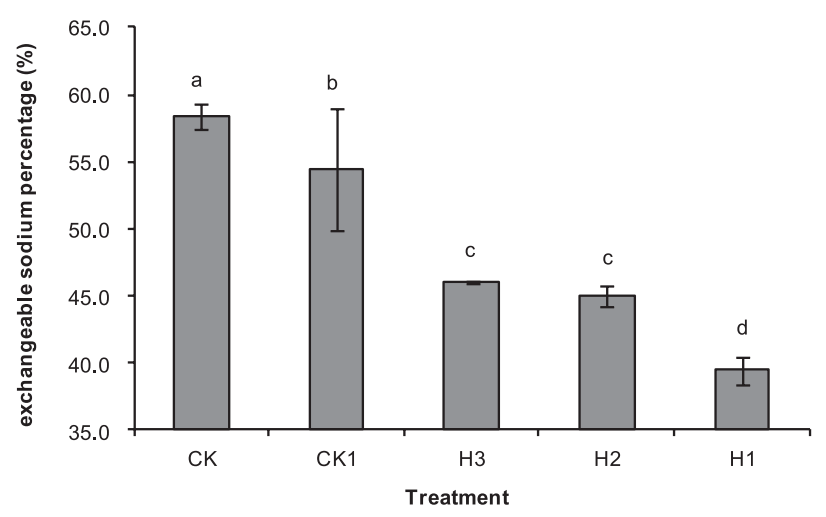

Fig. 5. Variation of soil-exchangeable sodium percentage (ESP) under different subsurface pipe depths; samples obtained in October 2012.

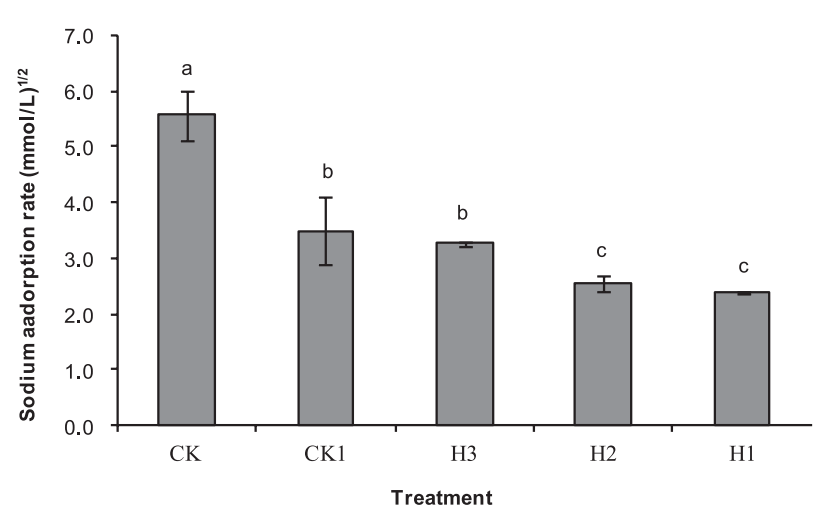

Fig. 6. Variation of sodium absorbance rate (SAR) under different subsurface pipe depths; samples obtained in fall 2012. 


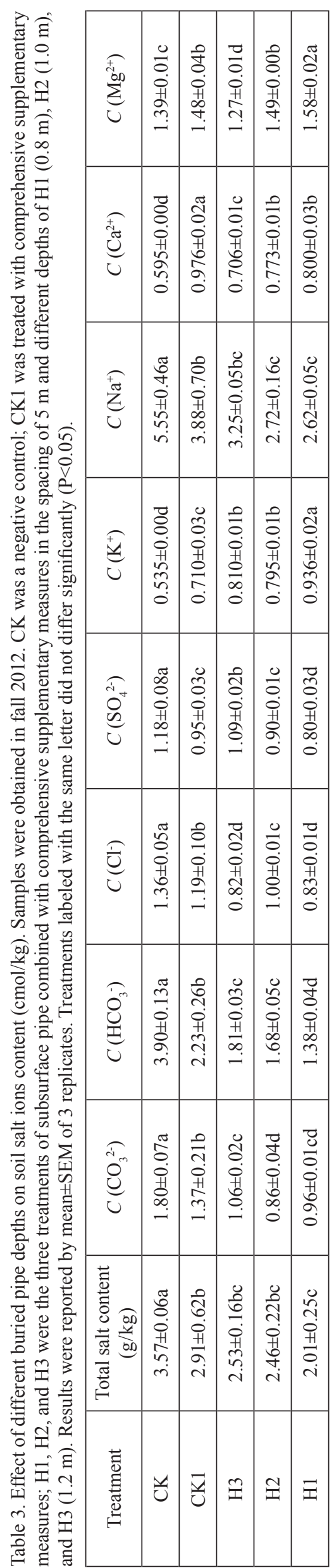

demonstrated that shallow buried subsurface pipe was prone to decreasing EC, which probably was because the saline water found it easier to reach the shallow subsurface pipe and drain out of the soil [37].

Soda meadow alkaline soil had higher contents of $\mathrm{Na}_{2} \mathrm{CO}_{3}, \mathrm{NaHCO}_{3}$, and exchangeable sodium, which severely damaged crop growth. Table 3 showed that the predominant ions in the study area were $\mathrm{HCO}_{3}^{-}$ and $\mathrm{Na}^{+}$. Compared to $\mathrm{CK}$, the content of $\mathrm{Cl}^{-}$and $\mathrm{SO}_{4}^{2-}$ significantly decreased $(\mathrm{P}<0.05)$ in $\mathrm{CK} 1$, whereas the content of $\mathrm{K}^{+}$significantly increased $(\mathrm{P}<0.05)$. Compared to $\mathrm{CK} 1$, the content of $\mathrm{Cl}^{-}$in the treatments of $\mathrm{H} 1, \mathrm{H} 2$, and $\mathrm{H} 3$ significantly improved. The content of $\mathrm{SO}_{4}^{2-}$ in the $\mathrm{H} 1$ treatment significantly decreased, but the content of $\mathrm{K}^{+}$in the treatment of $\mathrm{H} 1, \mathrm{H} 2$, and $\mathrm{H} 3$ significantly increased, indicating that a complex improving method and shallow buried subsurface pipe had an effect on the content of $\mathrm{Cl}^{-}, \mathrm{SO}_{4}^{2-}$, and $\mathrm{K}^{+}$. Owning to the main composition of TA with $\mathrm{Na}_{2} \mathrm{CO}_{3}$ and $\mathrm{NaHCO}_{3}$ in the study area, TA is recognized as the summary of the content of $\mathrm{CO}_{3}{ }^{2-}$ and $\mathrm{HCO}_{3}{ }^{-}$, which determined soil $\mathrm{pH}$ and other physicochemical characters [38]. TA variations in different treatments are shown in Fig. 4. TA in the $\mathrm{CK} 1$ treatment significantly decreased $(\mathrm{P}<0.05)$ compared to $\mathrm{CK}$, and TA in the treatments of $\mathrm{H} 1, \mathrm{H} 2$, and $\mathrm{H} 3$ also significantly decreased $(\mathrm{P}<0.05)$ compared to CK1. The results demonstrated that implementing the soil reclaiming method plus subsurface pipe greatly improved soil permeability and promoted saline water draining out of soil, leading to a TA decrease.

ESP was the percentage of sodium ion that soil colloid absorbed in CEC. It was considered that the higher the ESP, the stronger the soil alkalinity. The original soil ESP in Da'an was $66.56 \%$. The effect of different pipe depths on soil ESP is shown in Fig. 5. ESP was 58.39\% in the treatment of $\mathrm{CK}$, and reduced to $54.40 \%$ after utilizing fertilizer and other improvement measures. It showed a significant decrease in the treatments of $\mathrm{H} 1$, $\mathrm{H} 2$, and $\mathrm{H} 3$ compared to CK1. ESP was the lowest in the treatment of $\mathrm{H} 1$, indicating that CEC gradually increased but that total soil saline decreased owing to subsurface pipe installation. Lots of $\mathrm{Na}_{2} \mathrm{CO}_{3}$ and $\mathrm{NaHCO}_{3}$ were drained, leading to sodium ion absorbed by soil colloid being declined.

SAR described relative content of soluble sodium ion in soil. The value of SAR is higher in soda alkaline soil ranging from 4 to 8 [39]. The original soil SAR in Da'an was $7.64(\mathrm{mmol} / \mathrm{L})$. The variations of SAR in different treatments are shown in Fig. 6. Compared to CK, SAR in the treatment of CK1 was significantly reduced; and compared to $\mathrm{CK} 1, \mathrm{SAR}$ in the treatments of $\mathrm{H} 1$ and $\mathrm{H} 2$ significantly decreased as well. No significant decrease was seen in the treatment of $\mathrm{H} 3$. The results demonstrated that shallow buried subsurface pipe could rapidly decrease the relative content of sodium ions in the soil colloid, which was probably due to the exchange of matter and energy between paddy soil and irrigated water. Thus the harm of sodium ion to plants was reduced or eliminated. Afterward, the implementation 
of the complex improving method displaced lots of $\mathrm{Na}^{+}$, then leached with ground water and drained out of soil by subsurface pipe without accumulation. According to carbonate equilibrium in soil water, $\mathrm{CO}_{3}{ }^{2-}$ would transfer to $\mathrm{HCO}_{3}^{-}$with soil $\mathrm{pH}$ decreasing, which resulted in part of the carbonate being transferred to bicarbonate. Furthermore, $\mathrm{Ca}^{2+}$ and $\mathrm{Mg}^{2+}$ were ionized, leading to $\mathrm{Ca}^{2+}$ and $\mathrm{Mg}^{2+}$ content increasing [36].

\section{Conclusions}

Results reported here indicate that either comprehensive supplementary measures or subsurface pipe installation could significantly improve soil permeability, organic matter contents, available nitrogen, available potassium, and CEC. Soil $\mathrm{pH}, \mathrm{EC}, \mathrm{TS}, \mathrm{TA}$, and SAR were all decreased with the application of comprehensive supplementary measures or combined with subsurface pipe, and the later has a better effect. Moreover, the treatment with shallow buried pipe $(\mathrm{H} 1=0.8 \mathrm{~m})$ decreased more in soil $\mathrm{pH}, \mathrm{EC}$, and $\mathrm{SAR}$, and promoted more in rice yield than the other treatments. Based on these results, to ameliorate the soda saline-alkali area in Songnen Plain, an optimal treatment is suggested for shallow installation of subsurface pipe with $0.8 \mathrm{~m}$ in depth and $5 \mathrm{~m}$ in space, and at the same time combining with the application of comprehensive supplementary measures.

\section{Acknowledgements}

The project was financially supported by the National Key Research Projects of China (No. 2016YFD0200304) and the National Science and Technology Support Program of China (No. 2009BAC55B05). The authors thank the cooperating farmers for providing their farms as research. We also express our gratitude to the graduate and undergraduate students involved in the fieldwork.

\section{References}

1. MENG Q.F., Li D.W., ZHANG J., ZHOU L.R., MA X.F., WANG H.Y., WANG G.C. Soil properties and corn (Zea mays L.) production under manure application combined with deep tillage management in solonetzic soils of Songnen Plain. Northeast China. J. Integr. Agr. 15 (4), 879, 2016.

2. SUN G.Y., WANG H.X. Large scale development to salinealkali soil and risk control for the Songnen Plain. Resour. Sci. 38 (3), 0407, 2016 [In Chinese].

3. KANG Y.H., LIU S.H., WAN S.Q., WANG R.S. Assessment of soil enzyme activities of saline - sodic soil under drip irrigation in the Songnen plain. J. Paddy Water Environ. 11 (1-4), 87, 2013.

4. SHI W., TAKANO T., LIU S.K. Isolation and characterization of novel bacterial taxa from extreme alkali-saline soil. World J. Microbiol. Biotechnol. 28 (5), 2147, 2012.
5. CHI C.M., WANG Z.C. Characterizing salt-affected soils of Songnen Plain using saturated paste and 1:5 soil-towater extraction methods. Arid Land Res Manag. 24 (1), $1,2010$.

6. LIU S.H., KANG Y.H., WAN S.Q., WANG Z.C., LIANG Z.W., SUN X.J. Water and salt regulation and its effects on Leymus chinensis, growth under drip irrigation in salinesodic soils of the Songnen Plain. J. Agr. Water Manage. 98 (9), 1469, 2011

7. SHAYGAN M., READING L.P., BAUMGARTL T. Effect of physical amendments on salt leaching characteristics for reclamation. J. Geoderma, 292, 96, 2017.

8. CHI C.M.,ZHAO C.W., SUN X.J., WANG Z.C. Reclamation of saline-sodic soil properties and improvement of rice (Oriza sativa L.) growth and yield using desulfurized gypsum in the west of Songnen Plain, northeast China. J. Geoderma, 187-188, 24, 2012.

9. KHAN H.R., RAHMAN S., HUSSAIN M.S., BLUME H. Response of rice to basic slag, lime, and leaching in two saline-acid sulfate soils in pot experiments. J. Plant Nutr. Soil Sci., 159, 549, 1996.

10. SHARMA A., SINGH P., KUMAR S., KASHYAP P.L., SRIVASTAVA A.K., CHAKDAR H., SINGH R.N., KAUSHIK E., SAXENA A.K. Deciphering diversity of salt-tolerant bacilli from saline soils of easternindogangetic plains of india. Geomicrobiogogy. J. 32, 170, 2015.

11. WU Y.P., LI Y.F., ZHENG C.Y. Organic amendment application influence soil organism abundance in saline alkali soil. Eur. J. Soil Biol. 54, 32, 2013.

12. HAMMER E.C., NASR H., WALLANDER H. Effects of different organic materials and mineral nutrients on arbuscular mycorrhizal fungal growth in a Mediterranean saline dryland. Soil Biol. Biochem. 43 (11), 2332, 2011.

13. WANG T., AN F.H., DOU S., ZHANG Y.G., WANG C.Y. Effect of subsoiling on physical and chemical properties of soda meadow alkaline with being buried subsurface pipe. J. Jilin Agr. University. 34 (5), 545, 2012 [In Chinese].

14. DEELSTRA J. Climate change and subsurface drainage design: results from a small 377 field-scale catchment in south-western Norway. Acta Agr. Scand. 65, 58, 2015.

15. NOVAK S. M., PORTAL J. M., SCHIAVON M. Effects of soil type upon metolachlor losses in subsurface drainage. Chemosphere. 42 (3), 235, 2001.

16. KING K.W., WILLIAMS M.R., MACRAE M.L., FAUSEY N.R., FRANKENBERGER J., SMITH D.R., KLEINMAN P.J.A., BROWN L.C. Phosphorus Transport in Agricultural Subsurface Drainage: A Review. J. Environ. Qual. 44 (2), 467, 2015.

17. GUNN K., FAUSEY N., SHANG Y., SHEDEKAR V., GHANE E., WAHL M., BROWN L. Subsurface drainage volume reduction with drainage water management: Case studies in Ohio, USA. Agr. Water Manage. 149, 131, 2015.

18. DARZI-NAFTCHALI A., MIRLATIFI S., SHAHNAZARI A., EJLALI F., MAHDIAN M. Effect of subsurface drainage on water balance and water table in poorly drained paddy fields. Agr. Water Manage. 130, 61, 2013.

19. RITZEMA H., SATYANARAYANA T., RAMAN S., BOONSTRA J. Subsurface drainage to combat waterlogging and salinity in irrigated lands in India: Lessons learned in farmers' fields. Agr. Water Manage. 95 (3), 179, 2008.

20. LIU Z.Y. Application of subsurface drains in the Inland and arid and heavy saline area of the XinJiang uygur autonomous region. Irrigation drainage small hydropower station. 7, 9, 1994 [In Chinese]. 
21. RAO K.V.R., BHATTACHARYA A.K. Salinity distribution in paddy root zone under subsurface drainage. Agr. Water Manage. 48 (2), 169, 2001.

22. WISKOW E., PLOEG R.V.D. Calculation of drain spacings for optimal rainstorm flood control. J. Hydrol. 272, 163, 2003.

23. FURUKAWA Y.,SHIRATORI Y., INUBUSHI K. Depression of methane production potential in paddy soils by subsurface drainage systems. Soil Sci. Plant Nutr. 54 (6), 950, 2008.

24. SINGH R., HELMERS M.J., QI Z.M. Calibration and validation of drain mode to design subsurface drainage systems for Iowa's tile landscapes. Agr. Water. Manage. 85 (3), 221, 2006.

25. TIAN Y.F., DOU S., ZHANG Y.G., WANG C.Y., WU J.S. Improvement effects of subsurface pipe with different spacing on sodic-alkali soil. Transactions Chinese Society of Agr. Eng. 29 (12), 145, 2013 [In Chinese].

26. CZABAN J., WROBLEWSKA B., NIEDZ WIECJI J., SULEK A. Relationships between numbers of microbial communities in polish agricultural soils and properties of these soils, paying special attention to xerophilic/ xerotolerant fungi. Pol. J. Environ. Stud. 19 (6), 1171, 2010.

27. GAO L., SHEN G., ZHANG J. Accumulation and distribution of cadmium in flue-cured tobacco and its impact on rhizosphere microbial community. Pol. J. Environ. Stud. 24 (4), 1563, 2015.

28. WANG S.L., NAN Z.R., LIU X.W., ZHANG G.Z., ZHAO Z.J. Availability and speciation of $\mathrm{Cu}, \mathrm{Zn}$, and $\mathrm{Pb}$ added to irrigated desert soil. Pol. J. Environ. Stud. 19 (4), 865, 2010.

29. ROBERTS T., ROSS W., NORMAN R., SLATON N., WILSON C. Predicting nitrogen fertilizer needs for rice in Arkansas using alkaline-hydrolysable-nitrogen. Soil. Sci. Soc. Am. J. 75, 1161, 2011.
30. SSSC. Soil Science Society of China. Soil agricultural chemical analysis method. China agr. Sci. and technol. 1999 [In Chinese].

31. CAMBARDELlA C.A., ELliOTT E.T. Carbon and nitrogen distribution in aggregates from cultivated and native grassland soils. Soil Sci. Soc. Am. J. 57, 1071, 1993.

32. GELAW A.M., SINGH B.R., LAL R. Organic carbon and nitrogen associated with soil aggregates and particle sizes under different land uses in tigray, northern Ethiopia. Land Degrad Dev, 26 (7), 690, 2015.

33. TISDALL J.M., OADES J.M. Organic matter and waterstable aggregates in soils. Journal of Soil Science 33, 141, 1982.

34. LIU L.P., LONG X.H., SHAO H.B., LIU Z.P., TAO Y. Ameliorants improve saline-alkaline soils on a large scale in northern Jiangsu Province, China Ecol. Eng. 81, 328, 2015.

35. ZHANG F., XIONG H.G., AN F.Z. Classification of soil alkalization based on halophyte coverage. Acta Pedologica Sinica. 49 (4), 665, 2012.

36. HE B., CAI Y., RAN W., JIANG H. Spatial and seasonal variations of soil salinity following vegetation restoration in coastal saline land in eastern China. Catena. 118, 147, 2014.

37. YU J.B., LI Y.Z., HAN G.X. The spatial distribution characteristics of soil salinity in coastal zone of the Yellow River Delta. Environ. Earth Sci. 72 (2), 589, 2014.

38. LENTZ R.D., SOJIKA R.E. Field results using polyacrylamide to furrow erosion and infiltration. Soil Sci. 158, 247, 1994

39. LI B., WANG Z.C., WU H. Variations of alkalization parameters of soda solonetzduring dry and wet season. Soils. 42 (4), 639-643, 2010 [In Chinese]. 
